Science and Humanities Journal 14:83-95 (2020)

DOl: https://doi.org/10.47773/shj.1998.141.6

\title{
Instilling Environmental Consciousness through an Environmental Jamboree: The Experiences of Senior High School Students and Youth Leaders
}

\author{
Edrian Paolo B. Tulin', Hilda A. Pedrera², and Guiraldo C. Fernandez, Jr. ${ }^{3 \star}$
}

\begin{abstract}
This study is a documentation of the Visayas State University environmental consciousness drive for Senior High School students and youth leaders through an environmental jamboree in April 2018. Through quantitative and qualitative research methods, this study is designed to determine the Senior High School students and youth leaders' basic understanding of the essence of nature conservation and assess their learnings from the environmental jamboree lectures, environmentally-themed adventure race, and cultural night. In addition, this study enables the participants to develop personal reflections on their realizations of the importance of environment conservation. This study concludes that the environmental jamboree participants have little knowledge about environmental conservation at the start of the activity. Moreover, the participant's knowledge in the realm of nature conservation has significantly improved after they participated in the different activities of the environmental jamboree. Finally, the activities in the environmental jamboree have enabled the participants to realize that good ecosystem service only comes from a clean and healthy environment. Furthermore, this study reinforced another realization that environmental conservation efforts would be more successful if there is unity and coordination among people. Nevertheless, the participants were informed that such realizations could only materialize if there is determination and hard work among people involved in environmental conservation efforts.
\end{abstract}

Keywords: Environmental Jamboree, Environmental Consciousness, Senior High School

\section{INTRODUCTION}

The Philippines has been a frequent recipient of the adverse effects of the undesirable forces of nature for quite some time now. As the country faces the Pacific Ocean, it is more prone to storms, heavy rains, and landslides. In the past three decades, the country has experienced severe weather disturbances that have caused deaths by thousands. For instance, in November 2013, super typhoon Haiyan (Philippine name Yolanda) smashed the islands of Leyte and Samar in the southern part of the country with sustained winds at 196 miles per hour at landfall.

\footnotetext{
${ }^{1}$ Institute of Tropical Ecology and Environmental Management, Visayas State University, Visca, Baybay City, Leyte, Philippines

${ }^{2}$ Visayas State University Integrated High School, Visca, Baybay City, Leyte, Philippines

*Corresponding Author: Address: Department of Liberal Arts and Sciences, Visayas State University, Visca, Baybay City, Leyte, Philippines. E-mail:guiraldo.fernandez@vsu.edu.ph
} 
The cyclone left more than 6,300 confirmed deaths while thousands of others were missing (Singer, 2014). In the 1990s, similar catastrophic climate-induced calamities had also found their way to the shores of the Philippines. To mention one, on November 5, 1991, Typhoon Thelma (Philippine name Uring) bore down in Ormoc City, Leyte wreaking havoc and burying the city in water, sediments, and debris. The flash floods killed more than 4,000 people, injured 3,000 people, and about 2,500 more were reported missing (Francisco, 2016).

According to Filipino officials, rampant illegal logging and mining have been a big part of the cause for the high casualty count in solid typhoons in the Philippines. According to Benito Ramos, executive director of National Disaster Risk Reduction and Management Council (NDRRMC), "If we abuse nature, nature will get back at us." Secretary Ramos has observed that illegal logging and mining have stripped many hillsides bare in the Philippines, resulting in flash floods flow unimpeded, leading to cataclysmic land and mudslides that can bury whole towns (Hance, 2012). Aside from mining, another cause of forest loss could also be attributed to clearing secondary forests for upland agriculture (Fernando, 2016). With these, Filipinos need to care for the natural environment: otherwise they suffer the consequences of the harsh forces of nature.

One potent way to address this concern is through Environmental Education. In a country where storm visits are not unusual, there is a need to educate most, if not all, people to understand the causes and effects of such undesirable weather disturbances. With this, Government officials and Environmental advocates could craft strategies to mitigate the effects of typhoons and other related climateinduced catastrophes in their lives in particular and the community in general. However, educating people about environmental conservation is a long and quite demanding process. Nevertheless, it is not impossible to do since one can start from the simplest activities that may be interesting and enjoyable as well as facilitate learning the basics of taking good care of the natural environment. Hence, one can facilitate these kinds of activities. The vital thing to consider is to make people learn the importance of the natural environment to one's life through a variety of activities.

In line with this premise, the Institute of Tropical Ecology and Environmental Management (ITEEM), in cooperation with the Department of Liberal Arts and Behavioral Science (DLABS) of Visayas State University (VSU) and the Environmental Leadership Training Initiative (ELTI) of Yale University's College of Forestry and Environmental Studies conducted an Environmental Jamboree for Senior High School student leaders of Department of Education Baybay City Division. Among the participants are the youth leaders of Cabugcayan, Biliran Province, and the youth leaders of Pilar, Camotes Island, Cebu, which was done in April 2018. The activity was designed to give the incoming Grade 12 Senior High School student and youth leaders a realization of the importance of the natural environment concerning its capacity to sustain life on earth. The activity was composed of lectures from prominent personalities in environmental conservation, and environmentally-themed adventure race and cultural night. The activities were intended to provide the participants an avenue to learn and understand the interplay between human beings and the environment. With this, it was aimed that the participants would demonstrate the virtue of frugality towards Mother Nature.

The researchers from ITEEM designed activities that gave the participants 


\section{Environmental Consciousness Drive}

hands-on activities which provide insights that nature conservation is doable and possible in many instances. Moreover, the essence of the activities was designed to mainstream VSU's Natural Resource Management (NRM) Phase 2 project by giving the participants awareness of what VSU has been working on to enhance its thrust to contribute to the conservation of the natural environment. With this activity, the participants were given a glimpse of the intricate essence of Mother Nature and that the gifts given by nature to humankind must be fully understood and appreciated so that people would care for the natural environment's well-being.

Hence, in the pursuit to enable Senior High School students and youth leaders to gain more knowledge and awareness of the importance of Natural Environment, the following objectives were formulated: 1) To determine Senior High School students and youth leaders' basic understanding of the essence of nature conservation; and 2) To enable Senior High School students and youth leaders to come up with personal reflections on their realizations of the importance of Environment conservation.

\section{Hypotheses}

The null hypothesis $\mathrm{H}_{\mathrm{o}}$ There is no significant difference in the mean for pretest and posttest results.

The alternative hypothesis $\mathrm{H}_{\mathrm{a}}$ There is a significant difference in the mean for pretest and posttest results.

\section{Methodology}

The organizers of the Environmental Jamboree have prepared lectures, activities, and cultural night for the participants which are all environmentally themed. The environmentally-themed race has taken the form of basic Filipino games such as sack race, three-legged race, pick-up sticks, filling the bottle context, kayaking, and other similar races. The participants would race in groups from one point to another, where they will be exposed to the river, the sea, the hills, and the tree areas inside the VSU campus where the participants would be given occasions to appreciate and experience the beauty of the natural environment.

This study utilized both quantitative and qualitative research methods. In determining whether the Senior High School students have learned from the importance of environmental conservation and protection through the environmental lectures imparted to them and the environmentally themed adventure race and cultural night the quasi-experimental method was utilized, particularly the pretest and posttest design. The tool used for data collection was a structured questionnaire. The participants filled out a 10-item questionnaire with the same set of questions concerning the significance of the natural environment to a person's life before and after the training. Only the participants who answered the pretest and posttest were included in the analysis $(\mathrm{N}=50)$. The participants' test results were grouped into five categories: (1) very low, which consists of scores 0-2; (2) low, which consists of scores 3-4; (3) average, which consists of scores 5-6; (4) high, which consists of scores 7-8; and (5) very high, which consists of scores 9-10. Through the paired sample t-test, the significant differences between the pretest and posttest results were determined. 
In determining participants' realizations concerning the significance of the natural environment to their lives after the environmentally themed lectures, adventure race, and cultural night, this study utilized the hermeneutic qualitative research method. With this, this part of the paper employed the framework of Hans Georg Gadamer's hermeneutics. Hermeneutics concerned itself with the philosophy of interpretation, initially oriented towards the interpretation of texts. Hence, interpretation was used in deciphering what the texts in the participants' journals tried to convey. For Gadamer, "understanding was, essentially, a historically effected event " (Vanleuuuwen et al 2017). This study followed Gadamer's ontological interpretation that asserted that the truth had primarily been independent of any method and that people had been, in fact, interpretive beings. In one way or another, Gadamer looked at researchers as beings who were thrown into a world whose contexts molded them and limited their imagination and, hence, their options. The interpretation was the common ground of interaction between text and interpreter, by which each established their beings...interpreter and texts were indissolubly linked as a matter of being (Vanleeuwen et al 2017). Hence, in the ensuing process of interpretation, the texts revealed their meanings, ready to be understood by an interpreter. With these things given, the authors of this paper were as faithful as possible in deciphering the meaning of the texts considered in this study.

\section{Results and Discussions}

\section{Realizations on the Possibility of Nature Conservation}

In the thrust to mainstream the objectives of the Natural Resource Management Phase 2 through Environmental Education, ITEEM, DLABS, and ELTI invited Senior High Students and youth leaders from Baybay City, Leyte, Cabugcayan Biliran and Pilar, Camotes Cebu to take part and participate in an environmental jamboree designed to give said participants the basics of environmental conservation. Fifty participants responded to the call for participation. Before starting the activity, the participant's knowledge of the essence of nature conservation was gauged through a pretest.

Table 1 shows the socio-demographic profile of the environmental jamboree participants. All participants are currently studying in high school, aged 17-18. The majority of them are females, representing $60 \%$ of the total population, while the males represent $40 \%$. Most of the participants come from the different schools in the Baybay City Division of the Department of Education and some from Pilar Camotes, Cebu, and Cabugcayan, Biliran.

One noticeable thing in the composition of the participants is that majority of the participants in the environmental jamboree are women. Despite the country's patriarchal culture, the involvement of women in Philippine society has evolved through the years. Influences of women in the workplace and their significant contributions in the government, such as the women Presidents Corazon Aquino and Gloria Macapagal Arroyo, may have inspired and triggered the imagination of young women to be actively involved in activities that extend outside the home. Nevertheless, women's involvement in nature conservation initiatives has not been new in the government and the academe. For instance, one of the most vocal DENR 


\section{Environmental Consciousness Drive}

secretaries was the late Gina Lopez, a staunched critic of mining companies in the Philippines. In the academe, Dr. Paciencia Milan, the only woman President of Visayas State University, also conceptualized Rainforestation, a conservation innovation that made use of Philippine native tree species that was adopted by the Department of Environment and Natural Resources as a national reforestation strategy in 2004.

Table 1. Socio-demographic Profile of the Environmental Jamboree Participants

\begin{tabular}{cccc}
\hline & & \multicolumn{2}{c}{ Research Sample $(\mathrm{n}=50)$} \\
& & Number of \\
Respondents & Percentage \\
\hline Demographic Variables & Male & 20 & $40 \%$ \\
\hline Sex & Female & 30 & $60 \%$ \\
\hline Age & 16 or younger & 0 & 0 \\
& 17 & 34 & $68 \%$ \\
& 18 & 16 & $32 \%$ \\
& 19 or older & 0 & 0 \\
\hline Education Level & Primary & 0 & 0 \\
& Secondary & 50 & $60 \%$ \\
\hline Location & Baybay City, Leyte & 30 & $20 \%$ \\
& Pilar Camotes, Cebu & 10 & $20 \%$ \\
\hline
\end{tabular}

To enlighten the student and youth leaders about the importance of environment conservation, lectures on environment conservation were given to the participants. These lectures were given to the students by the experts in environmental conservation such as Dr. David Neidel of the Environmental Leadership Training Initiative (ELTI) of Yale University School of Forestry and Environmental Studies, Dr. Paciencia Milan, the brain behind the Rainforestation technology, and former president of the Visayas State University, Mr. Rene Vendiola, a Ramon Aboitez Foundation Incorporated (RAFI) Triennial Awardee for exemplary individuals for forest conservation and Sister Geraldine Villaluz, Religiosae Sanctissimi Cordis Jesu (RSCJ) from the University of San Carlos School of Education. The four resource persons spoke of different lenses on how to view the importance of the natural environment and the different initiatives on how best to conserve and preserve the natural environment.

Table 2 shows the distribution of pretest and posttest results. During the pretest, it was found that $48 \%$ of the participants had high to very high knowledge of environmental conservation's essence and operations, and $52 \%$ had very low to average knowledge. 
Table 2. Distribution of Pretest and Posttest Results

\begin{tabular}{ccccc}
\hline \multirow{2}{*}{ Scores } & \multicolumn{2}{c}{ Pre-test } & \multicolumn{2}{c}{ Post-test } \\
& Frequency & Percentage & Frequency & Percentage \\
\hline 1 & 0 & 0 & 0 & 0 \\
2 & 1 & $2 \%$ & 0 & 0 \\
3 & 3 & $6 \%$ & 0 & 0 \\
4 & 6 & $12 \%$ & 0 & 0 \\
5 & 5 & $10 \%$ & 0 & 0 \\
6 & 11 & $22 \%$ & 7 & $14 \%$ \\
7 & 14 & $28 \%$ & 12 & $24 \%$ \\
8 & 7 & $14 \%$ & 14 & $28 \%$ \\
9 & 3 & $6 \%$ & 8 & $16 \%$ \\
10 & 0 & 0 & 9 & $18 \%$ \\
\hline Total & 50 & $100 \%$ & 50 & $100 \%$ \\
\hline
\end{tabular}

Looking at the inputs by the resource persons in the 2018 Environmental jamboree, it is pretty clear that the student participants have positive views on what the resource persons have imparted to them. Table 3 shows how the participants have rated the essence of the lectures and the performance of the resource persons.

Table 3. Results of the Performance Evaluation of the resource persons and the essence of their lectures

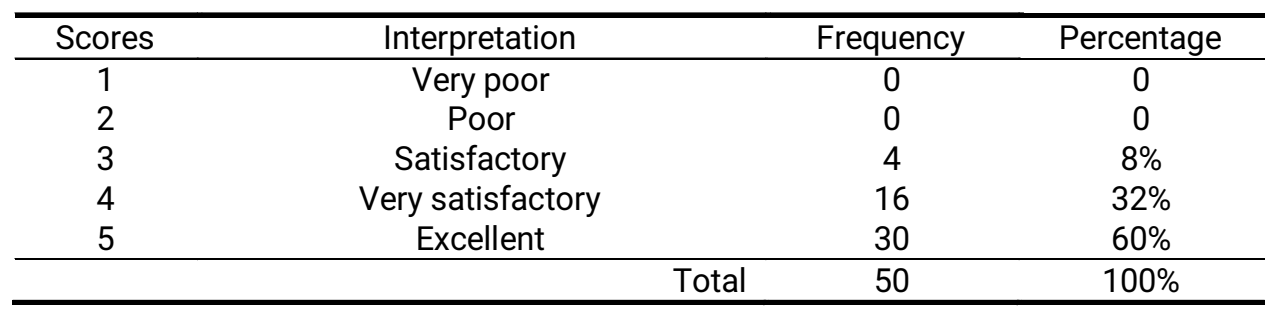

Table 3 shows how the participants have rated the essence of the lectures and the performance of the resource persons. It shows that $8 \%$ of the population, which is equivalent to 4 participants, have given the lecturers a score of 3 , which corresponds to satisfactory performance; $32 \%$ or 16 participants have given a score of 4 , which corresponds to very satisfactory performance, and $60 \%$ of the population comprising to 30 participants have given the lecturers a score of 5 which corresponds to an excellent performance. Thus, the data show that the lecturers have performed well enough to cater to the necessary information about environmental conservation.

The Student Participants' View on Environment Conservation with their Participation in the Different Activities of the Environmental Jamboree.

In the thrust to enable the student participants to internalize what was taught to them through a series of environmentally related lectures, the student participants were made to participate in an environmentally-themed adventure race and cultural night. The environmentally-themed adventure race was designed to enable the 


\section{Environmental Consciousness Drive}

participants to realize the necessity to conserve the natural environment as it gives essential ecosystem services to humankind. The student participants were grouped into four. They had to race with the other groups by achieving what was asked of them in a given station. Moreover, the adventure race was also designed to make the participants appreciate the marine resources, the river ecosystem, and the terrestrial ecosystem. The notion of race was put into play to emphasize that people had to race against time in conserving what was left in nature. The participants were also divided into groups to emphasize that teamwork and coordination among people are essential elements in the quest to protect the wellbeing of the natural environment.
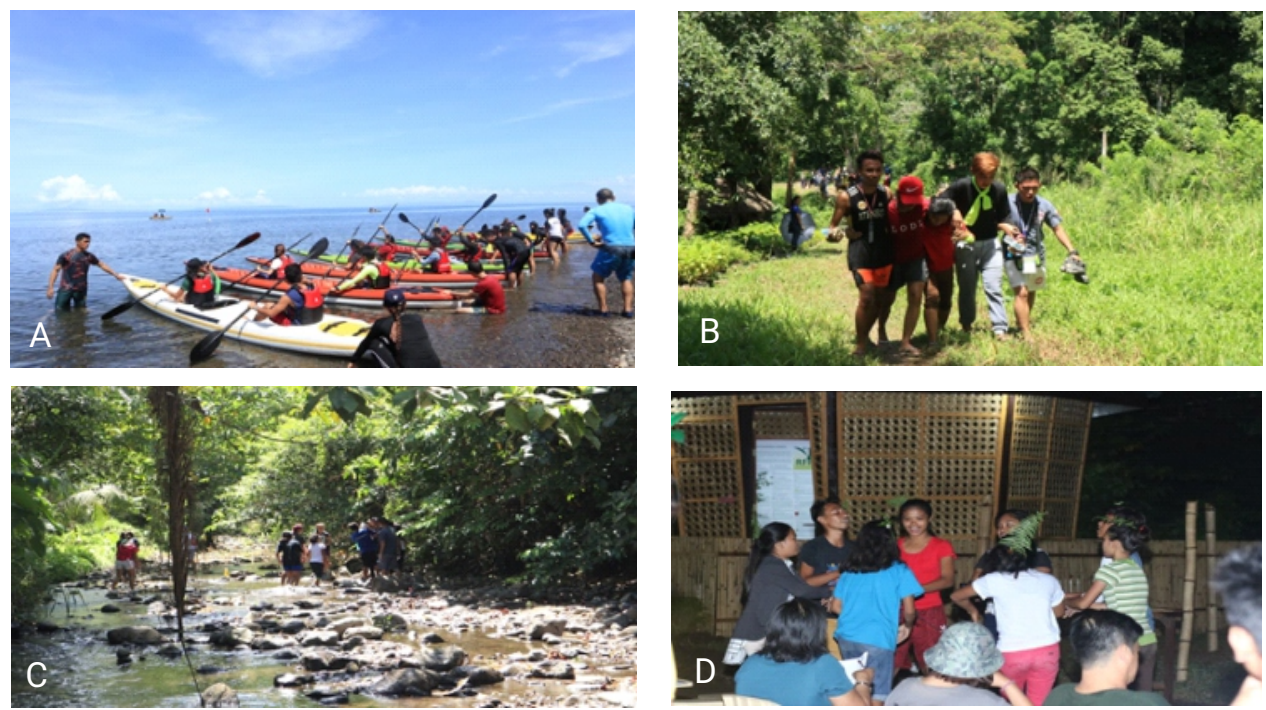

Figure 1. (A) Sea Ecosystem Kayak Race (B)Terrestrial Ecosystem Three-legged Race (C) Looking for Something at the River Ecosystem (D)Participants Performing an Environmentally Inspired Song and Dance at the Cultural Night (Photo courtesy of Dr. Bethlehem Ponce)

The environmentally-themed adventure race was based on the premise that the participants would appreciate the importance of the natural environment if they had first-hand experienced in communing with Mother Nature themselves. This activity was also based on the "Learning by Doing Principle" where students learned the importance of the natural environment when they get involved in activities designed to enable them to be in touch with nature. In adventure race activity, "Learning by Doing" was noticeable in teamwork, such as responsibilities, work capacities, occurring conflicts, and strategies that reflected how the participants gave their all in the activity. On the other hand, "Learning by Doing" also manifested a high degree of flexibility to change involving windows of opportunities and availability of support (Block et al., 2016) among the participants who had not known each other when they arrived for the environmental jamboree.

Moreover, the environmentally-themed adventure race was also in line with the objectives of environmental education. For one, Environmental Education has aimed to help social groups and individuals acquire an awareness of and sensitivity 
to the total environment and its allied problems. It zeroed in on the aspect to help people gain various experiences and acquire a basic understanding of the environment and its associated problems (Biedenweg et al., 2013). By immersing the student participants with the generosity of the natural environment, they were already given the occasion to understand that there was no way for them to enjoy the goodness of nature if the river and the trees had been grossly exploited and polluted. Such activity allowed them to acquire an awareness of and sensitivity to the total environment and its allied problems, gain a variety of experiences, and acquire a basic understanding of the environment and its associated problems.

Furthermore, the environmentally-themed cultural night also served as an occasion for the proliferation of Environmental Education. The students performed songs and dances of how individuals should care for the environment in the most effective ways. The participants expressed their message for environmental conservation through songs and dances. At the same time, the activity itself was tagged as "Mga Awit ug Sayaw Para sa Kinaiyahan" (Songs and Dances for the Natural Environment). This activity again manifested semblances of the objectives of Environmental Education since it provided an opportune space for the participants to acquire a set of values and feelings of concern for the environment. Aside from that, the participants were also motivated to participate in activities geared toward environmental improvement and protection. Overall, the said activity was instrumental in helping the participants acquire the skills for identifying and solving environmental problems and providing them with a chance to be actively involved at all levels in working toward the resolution of environmental problems (Biedenweg et al., 2013).

With the environmental lectures and the variety of environmentally-themed activities experienced by the participants, it might have been possible that their understanding of the importance of the natural environment to people's lives has significantly improved. After all, the said activities are in line with the objectives of Environmental Education. Hence, students' knowledge regarding these things has been measured through a posttest administered to the participants after all the lectures have been given and after the entire environmentally-themed adventure race and the environmentally-themed cultural night have been finished. This evaluation has been conducted to determine how the participants have perceived the essence of environmental conservation.

Table 4 shows the relationship between the results of pretest and posttest. This table concludes that there is a significant relationship between the results of pretest and posttests; therefore, the null hypothesis is rejected. It means that after the environmental jamboree, the participants have learned from the discussions conducted and the environmentally themed activities undertaken. This manifests that the environmental lectures and the environmentally themed adventure race and cultural night have significantly improved the understanding of the Senior High School student and youth leaders of the importance of the natural environment to a person's life.

Table 4. Relationship between the Results of Pre-test and Post-test

\begin{tabular}{ccc}
\hline Variables & Significant Value & Judgment \\
\hline Pre-test and Post -test & $<.000$ & Reject null hypothesis \\
\hline
\end{tabular}




\section{Environmental Consciousness Drive}

\section{Reflections and Realizations of the Importance of Environment Conservation}

After the 2018 Environmental Jamboree, the participants have arrived at significant realizations and learnings of the significance of the natural environment in sustaining life on earth. The realizations and reflections had been written in personal journals as part of the activity in the Environmental Jamboree. As required by ethics, the organizers have requested the participants to allow the activity organizers to randomly read their journals in part or whole as part of the activity's evaluation process. Fortunately, the majority of the participants have given their consent to said request which enabled the organizers to uncover themes regarding how the participants view the activity.

\section{Emerging Themes}

A good ecosystem service comes from a healthy environment. The participants manifested that it was important for people to care for the natural environment. One of the participants realized that kayaking would have been an enjoyable activity if the sea is not polluted and felted with trash and other undesirable pollutants. He continued by asserting that had it been the case, he would have second thoughts in participating in the activity. However, the sea was clean and blue during that time, and it seemed to beckon him to immerse himself into the water and enjoy the coolness and freshness of the sea. This observation was reinforced by another participant who also asserted that the kayak race was one of the most enjoyable activities of the environmental jamboree. She was convinced that the water was safe for her skin and her whole well-being. She admitted that she did not get any problem with taking part in the activity since the sea was clean when she arrived at the beach for the kayak race. As the male participant put it:

"Nindot jud kaayo ang pag-kayak namo sa dagat kay limpyo ug linaw kayo ang dagat. Wala jud basura nga makita ug sigurado ko safe siya bisan makaligo pa ko sa dagat. Pero kung hugaw pa to ang dagat ug daghang basura didto, tingali dili ko moapil sa kayak race."

"We had a great time kayaking in the sea because the sea was clean and very clear. There was no trash to be seen, and I was sure it was safe even if I bathe in the sea. However, if the sea was dirty and there was much trash, I would probably not join the kayak race."

A female participant also added:

"Nag-enjoy jud kaayo ko sa kayak race. Nag-amping man jud ko sa ako panit no, pero sa kalimpyo sa dagat, miapil jud ko sa activity kay sigurado ko nga dili madaot ang akong panit sa kahugaw kay limpyo jud kaayo ang dagat. Kung hugaw pa ang dagat, wala jud bisan usa nga mag-enjoy."

"I really enjoyed the kayak race. I was careful with my skin, but due to the cleanliness of the sea, I participated in the activity because I was sure that 
the dirt would not damage my skin. After all, the sea is immaculate. If the sea is dirty, no one will enjoy it."

Moreover, another participant also claimed that the environmentally-themed adventure race was very tiring since he and the other participants were made to run from one point to another to accomplish a specific requirement for the race. Nevertheless, the calm and clean air in the vicinity of the Visayas State University campus and trees everywhere made the activity less tiring. The greenness of the trees during summer and the symmetry of the view of the adventure race venue made the activity worth its value. Had the trees been absent in the race venue, the ambiance could have been very hot, and many participants would hesitate to join the activity. As one participant had it:

"Kapoy jud kaayo ang adventure race. Pero tungod kay daghan og kahoy ang palibot sa VSU, bugnaw ra jud ang kadaghanan sa mga lugar sa adventure race. Maayo gani naa ang mga kahoy kay kung wala pa to, perti jud unta kaayo ang ka init. Kung init pa to, dili jud enjoyable ang duwa. So maayo jud nga i-preserve ang mga kahoy kay magdala jud sila og landong ug kabugnaw sa palibot."

"The adventure race was very tiring. But because there are many trees around VSU, most of the adventure race areas are just cold. It was good that the trees are there because if they were not there, it would have been scorching hot. If it were hot, the game would not be enjoyable. So it is good to preserve the trees because it would bring shade and coolness around."

Aside from that, another participant also claimed that the clean river where she and her fellow participants had been made to tread allowed her to experience the coolness of the water and the wonderful feeling of engaging oneself with the best that nature has given to humankind. Thus, she realized that people should take care of the river so that more people could enjoy the coldness of its water and more living beings' thirst could be quenched from its safe and unpolluted state. She also asserted that it would have been a different experience had the river been dirty and polluted. Looking at the participants' experiences, it was pretty clear that the healthy and clean environment in the environmental jamboree venue had given the participants a realization that it was important for the environment to be clean.

Unity and coordination offer the greater possibility to achieve goals. One of the participants had written in his journal that staying united and coordinated enabled them to finish the race ahead of others. He specifically wrote that kayaking, the three-legged race, and the other activities in the environmentally-themed adventure race and cultural night had been indirectly designed to enable them to value teamwork and coordination in order to achieve a particular task. In kayaking, for instance, the participants have to coordinate how to paddle and act as if they were paddling as one person and not as two individuals.

A participant in the three-legged race had also noticed this observation. According to the participant, it was impossible to move fast in the race if coordination was absent among the individuals involved. Since there were five 


\title{
Environmental Consciousness Drive
}

participants involved and made to use only three legs to be functional in the race, speed would be impossible without coordination. Hence, the participants have to move as one and manage the feet' movement as if receiving a single person's command, and not from five individuals. It would enable the participants to move faster and arrive at the finish line at a faster pace. With coordination and teamwork, the individuals involved in the race did not stumble very often and were faster in pace than those who did not coordinate their movements. Overall, the individuals who experienced the kayak race and the three-legged race had expressed in their journals that the same would also be true in conserving the natural environment. Had people only coordinated their actions towards nature conservation, it would have been more successful in many parts of the Philippines. As a participant from Pilar, Camotes Island, had it:

\begin{abstract}
"Sa ako pagtan-aw, gipa-learn mi og lesson sa mga organizers sa mga dula nga ako giapilan nga importante jud ang coordination aron mupaspas mi sa among movement sa mga lumba nga amo giapilan. Naka-realize ko nga pareha sa pag-amping ug pag-save nato sa kinaiyahan, kinahanglan jud naay coordination ang mga tawo. Aside ana, kinahanglan pod nga naay pareha og paglantaw ang mga tawo nga importante ang kinaiyahan sa kinabuhi sa matag usa".
\end{abstract}

"In my opinion, we were taught by the organizers that coordination was necessary to speed up our movement in the races we participated in. I realized that similar to taking care and saving our environment, people must have coordination. Aside from that, people also need to have the same perspective that nature is essential in each one's life."

To achieve something entails a lot of determination and handwork. Determination and handwork in achieving a particular task were the essence of two of the participants' reflection as discernible in their journals. According to a male participant, determination had played a crucial role among his fellow participants in finishing the environmentally-themed adventure race. According to him, the race was done in summer, and the weather was scorching. Hence, finishing the race entailed determination in accomplishing the task at hand.

The experience of a female participant collaborated with what the abovementioned male participant had asserted. According to her, the race was very tiring, and there was a time that she already wanted to quit the race. However, she was encouraged by her teammates to go on. The encouragements gave her the strength and determination to finish the race and inspired her to work hard together with her teammates to finish what they had started.

Looking at the significant realizations of the two participants, both of them had signified that nature conservation entailed a lot of determination and hard work in order for the present generation to conserve or preserve what is left of the natural environment. Hence, people should be determined and resolve to work hard to protect and conserve Mother Nature. 


\section{Conclusions}

This study concludes that the Senior High School students and youth leaders from Baybay City, Leyte Division of the Department of Education, the youth leaders from Cabugcayan, Biliran Province and Pilar, Camotes, Cebu have learned the significance of the natural environment to people's lives through the lectures by experts and practitioners of environment conservation.

This study further concludes that the jamboree activities have significantly improved the understanding of the Senior High School student and youth leaders of the importance of the natural environment. It is manifested in the posttest results that $86 \%$ of the participants had high to very high knowledge of environmental conservation's essence and operations; $14 \%$ had average knowledge, and no one had low to very low knowledge. This result contrasts with the pretest results, which manifests that only $48 \%$ of the participants had high to very high knowledge of environmental conservation's essence and operations, and $52 \%$ had very low to average knowledge. This study has signified that the increased awareness and knowledge on the importance of the natural environment to people's lives have been acquired by the participants through the "Learning by Doing Principle." The students learn of the importance of the natural environment when they themselves get involved in activities designed to enable them to be in touch with nature.

Lastly, this study concludes that the participants have been indirectly taught three essential lessons. First, they realized that an ecosystem service naturally comes from a clean and healthy environment. Hence, to enjoy the things given by nature, people ought to keep the environment healthy and clean. Second, the participants also realized that the more united and coordinated the people are, the greater the possibility of achieving something. The participants have arrived at this realization because of the "learning by doing" principle, facilitated by the different activities in the environmental jamboree. The participants then relate this to the conservation efforts in the county, which could be more successful if coordination and unity are present among the people. Third, the students also realized that conserving or protecting what is left to the natural environment entails a lot of determination and hard work. Just as finishing and winning the environmentallythemed adventure race, the participants have also realized that racing against time to conserve or preserve what is left in nature also entails determination and hard work.

\section{References}

Biedenweg K, Monroe M, \& Wojcik D. 2013. Foundations of Environmental Education. In M. Monroe \& M. Krasny (Eds.), Across the Spectrum: RESOURCES FOR ENVIRONMENTAL EDUCATORS (pp. 9-28). North American Association for Environmental Education.

Block M, BraBler M, Orth V, Riecke M, Rodriguez Lopez JM, Perino G, \& Lamparter M. 2016. Dies Oecologicus-How to Foster a Whole Institutional Change with a Student-Led Project as Tipping Point for Sustainable Development at Universities. In W. Leal Filho \& P. Pace (Eds.), Teaching Education for Sustainable Development at University Level (pp. 341-355). Springer International Publishing. doi:DOI 10.1007/978-3-319-32928-4_24 


\section{Environmental Consciousness Drive}

Fernandez GC and Villaluz GD. 2018. The Natural Environment as a Significant Factor in Farmers and Fishermen's Notions of Peace. Annals of Tropical Research, 40(1), 124-136.

Fernandez GC and Bande MJM. 2019. Rainforestation and Sustainable Development: The Lived Experience of the Four Individual Adopters from the Visayas Region in the Philippines. Recoletos Multidisciplinary Research Journal, 7(2), 29-46.

Fernando E. 2016. Classifying Natural and Restored Forests Containing Primary, Secondary Growth, or Residual Forests. PANAO.Rain Forest Restoration Initiative, 3.

Francisco K. 2016. The 1991 Flash Flood that Devastated Ormoc. Retrieved July 23, 2018, from https://www.rappler.com/newsbreak/flashback/151178-lookback-1991-flash-flood-ormoc

Goltenboth F. 2011. "Rainforestation farming" - An Appropriate and Applied Ecological Approach for Landscape Rehabilitation and Impact Mitigation of Climate Change in the Humid Tropics. Annals of Tropical Research, 33(2), 85-106.

Hance J. 2012. Illegal logging, mining worsened impact of Philippines' killer typhoon. Retrieved May 07, 2020, from https://news.mongabay.com/ 2012/12/illegal-logging-mining-worsened-impact-of-philippines-killertyphoon/

Singer M. 2014. 2013 State of the Climate: Record-breaking Super Typhoon Haiyan. Retrieved March 26,2020, from https://www.climate.gov/newsfeatures/understanding-climate/2013-state-climate-record-breaking-supertyphoon-haiyan

Vanleeuwen C, Guo-Brennan L \& Weeks L. 2017. Conducting Hermeneutic Research in International Settings: Philosophical, Practical, and Ethical Considerations. Journal of Applied Hermeneutics, 1-23. 